\title{
Spatial analysis for bovine viral diarrhea virus and bovine herpesvirus type 1 infections in the state of Paraíba, northeastern Brazil
}

Leíse Gomes Fernandes ${ }^{1}$, Edviges Maristela Pituco ${ }^{2}$, Adriana Hellmeister de Campos Nogueira Romaldini², Eliana De Stefano ${ }^{2}$, Inácio José Clementino ${ }^{3}$, Amanda Rafaela Alves Maia', Carolina de Sousa Américo Batista Santos ${ }^{1}$, Clebert José Alves ${ }^{1}$ and Sérgio Santos de Azevedo ${ }^{1 *}$

\begin{abstract}
Background: Bovine Viral Diarrhea Virus (BVDV) and Bovine Herpesvirus type 1 (BoHV-1) cause reproductive problems in cattle and restrictions on international trade in animals worldwide. Both infections were detected in cattle herds in the Paraíba state, Northeastern Brazil, however, the spatial distribution and geographic identification of positive herds for these viruses has never been examined. Therefore, the aim of this study was to describe the spatial pattern of apparent prevalence estimate and to identify spatial clustering of positive herds of BVDV and BoHV-1 infections in cattle herds from the state of Paraíba, Northeastern Brazil.

Results: The herd-level prevalence for BVDV and BoHV-1 infections in Paraíba were, respectively, 65.5\% (95\% Cl: 61. 1-69.7) and 87.8\% (95\% Cl: 84.5-90.5). The average apparent within-herd prevalence of BVDV was $31.8 \%$ and of BoHV-1 was $62.4 \%$. The predicted prevalence was highest (0.42-0.75) for BVDV in the west, north and eastern part of Sertão and in the central and eastern part of Agreste/Zona da Mata. For BoHV-1, the highest predicted prevalence (0.74-0.97) was in some local areas across Sertão and throughout the eastern part of Agreste/Zona da Mata. Six significant clusters were detected for BVDV, a primary cluster covering the eastern Sertão region, with 11 herds, radius of $24.10 \mathrm{~km}$ and risk relative (RR) of $2.21(P<0.001)$ and five smaller significant clusters, involving one or two herds in Agreste/Zona da Mata region with a high RR. A significant clustering of BoHV-1 positive herds $(P<0.001)$ was detected in Agreste/Zona da Mata region with a radius of $77.17 \mathrm{~km}$ and a RR of 1.27 , with 103 cases. Consistency was found between kriging and SatScan results for identification of risk areas for BVDV and BoHV-1 infections.

Conclusions: The clusters detected contemplated different areas of the state, with BVDV cluster located in the Sertão and BoHV-1 in Agreste/Zona da Mata stratum. Through the risk mapping, it was possible to identify the areas in which the risk is significantly elevated, coincided with areas where there are borders with other states and in which there is a high movement of animals.
\end{abstract}

Keywords: Cattle, Epidemiology, Cluster analysis, BVDV, BoHV-1, Kriging estimate

\footnotetext{
* Correspondence: sergio@vps.fmvz.usp.br

${ }^{1}$ Laboratory of Transmissible Diseases, Academic Unit of Veterinary Medicine,

Center of Rural Technology and Health, Federal University of Campina

Grande, Patos, PB 58700-970, Brazil

Full list of author information is available at the end of the article
} 


\section{Background}

The reproductive infectious diseases are those that cause more damage in productivity in cattle herds, assuming importance viral agents, especially Bovine Viral Diarrhea Virus (BVDV) and Bovine Herpesvirus type 1 (BoHV-1), which cause reproductive problems in both beef and milk cattle, and restrictions on international trade for animals and animal products [1-3].

BVDV is a member of the genus Pestivirus, which belongs to the Flaviviridae family, and although capable of manifesting in different clinical presentations and acute, sub acute or chronic character, the reproductive consequences of this virus and its persistent infection have greater economic and epidemiological importance $[4,5]$. The transmission may occur by a wide range of body fluids (nasal discharge, urine, milk, semen, saliva and fetal fluids), indirect contacts (airborne transmissions, contaminated material or iatrogenic) and via the placenta to the fetus, resulting in the birth of an immunotolerant and persistently infected (PI) calf [6]. The PI animals result from uterine exposure to noncytopathic strains of BVDV before development of fetal immunocompetence (generally before 125 days of gestation) [7] PI calves are often weak at birth or die before one year of age, but others may not show clinical signs, being epidemiologically important due to shed large amounts of virus, acting as constant sources of infection for susceptible animals [8]. The detection and removal of PI animals and vaccination of susceptible animals are key strategies for the control of herds from BVDV $[9,10]$.

The BoHV-1 is a alphaherpesvirus belonging to the genus Varicellovirus, which infects cattle and presents clinical manifestations such as pustular vulvovaginitis or balanoposthitis, abortion, rhinotracheitis and meningoencephalitis, and causes great economic losses to the livestock industry $[11,12]$. This virus may be transmitted by respiratory and genital secretions of infected individuals through direct and indirect contact, such as contaminated materials, contaminated semen or airbone transmission [13]. BoHV-1 has the ability to cause latent infections, and periodically, BoHV-1 may be reactivated, and then shed and transmitted, which guarantees its perpetuation and spread in herds, thus being the main obstacle to the establishment of control measures [14].

The seroprevalence of BVDV and BoHV-1 have numerous references available all over the world, with variable values, but generally higher, depending on the control measures practiced [15]. In Brazil, regional data obtained from serological surveys reveal significant spread of the virus in beef and dairy herds [16-18]. In the state of Paraíba, Thompson et al. [19] found antiBVDV antibodies in $22.2 \%$ of animals and $88.9 \%$ of herds and anti-BoHV-1 antibodies in $46.6 \%$ of animals and $100 \%$ of herds. These authors concluded that the within- herd spread of BVDV and BoHV-1 were relatively slow and its ubiquitous nature makes it difficult to generalize the rate of among-herds spread.

BVDV and BoHV-1 infections occur in cattle herds in the state of Paraíba, however, the spatial distribution and geographic identification of positive herds for these viruses has never been examined. According to Carpenter [20], whether it is an outbreak investigation or epidemiological research, more emphasis should be placed on the spatial and temporal components of health events in order to identify unusual occurrences of events that happen close together in either time and/or space.

Spatial analysis of infectious diseases allows for the detection of disease clusters, which can occur due to common risk factors among herds or the transmission between neighbors herds, being a useful tool in epidemiological surveillance providing better visualization and hypothesis survey for the occurrence of clusters, facilitating the elaboration of control strategies [21]. Hence, the present study aimed to describe the spatial pattern of apparent prevalence estimate of BVDV and BoHV-1 infections in cattle herds from the state of Paraíba, Northeastern Brazil, including identification of areas with increased risk of occurrence of these viruses.

\section{Methods \\ Characterization of the study area}

The state of Paraíba, located in the Northeastern region of Brazil, is characterized by warm weather throughout the year. The state is geographically subdivided into the following four regions, based mostly on vegetation type and rainfall: (i) Zona da Mata (Atlantic forest), (ii) Agreste, (iii) Borborema, and (iv) Sertão. The Zona da Mata and Agreste have relatively higher rainfall regimes [22]. Borborema and Sertão (semi-arid region) are typically within the Caatinga biome, a xeric forest and a forest of thorns composed by cacti, thick plants, spiny brush and adapted arid grasses [23]. The climate is characterized by a warm and semi-arid climate, with average temperatures of $27^{\circ} \mathrm{C}$, and the average annual rainfall is typically $\approx 500 \mathrm{~mm}$. There are typically two seasons: a rainy season from February to May, and a long drought period from June to January. However, occurrences of droughts lasting more than one year are also characteristic of the region [24].

The animal husbandry has an increasingly important in the Agreste, Borborema and Sertão regions, where small cattle-raising farms and family farms are widespread. The cattle are usually reared extensively on native Caatinga in most of the Borborema and Sertão farms. Following the Brazilian scenario of milk production, in the state of Paraíba around 69\% of milk was produced in small cattle-raising farms [25]. 


\section{Data source}

The data used in this study were obtained from a survey of bovine brucellosis in the state of Paraíba made by the National Program for Control and Eradication of Brucellosis and Tuberculosis, in which samples were collected from September 2012 to January 2013. In total, 2443 cows aged $\geq 24$ months were sampled from 478 herds.

\section{Study design}

The state of Paraíba was divided into three sampling groups: sampling stratum 1 (mesoregion of Sertão), sampling stratum 2 (mesoregion of Borborema), and sampling stratum 3 (mesoregions of Zona da Mata and Agreste) (Fig. 1). When this stratification scheme was proposed, the operational capacity of the Agricultural and Livestock Defense Service of the State of Paraíba (SEDAP) was considered based on the areas of action of its regional units in order to ensure that the veterinarians and agricultural and livestock technicians from the SEDAP could conduct the fieldwork. For each sampling stratum, a pre-established number of herds with reproductive activity (primary sampling units) were randomly selected and then, a pre-established number of unvaccinated cows aged $\geq 24$ months were randomly and systematic selected (secondary sampling units), using the following criteria: 10 animals were sampled in herds with up to 99 cows aged over 24 months; 15 animals were sampled in herds with 100 or more cows aged over 24 months; and all animals were sampled in those with up to 10 cows aged over 24 months.

The field activities included blood collection and sending the samples to the laboratory. The coordinates in each herd were identified using a global positioning system device (GPS).

\section{BoHV-1 and BVDV serological diagnosis}

For the serological diagnosis of BVDV and BoHV-1 infections the virus-neutralization test was used [26, 27]. The cytopathic viral strains BVDV-1 (NADL) and BoHV-1 supplied by the Virology Institute of the Veterinary Medicine College of Hanover, Germany were used. The technique was performed in two stages, screening and titration, and a sample was considered positive when it presented a titer $\geq 10$ for BVDV and $\geq 2$ for BoHV-1. The neutralizing antibodies titers were considered the reciprocal of the higher serum dilutions capable of inhibiting the viral replication and the consequent production of cytopathic effect of BVDV and BoHV-1. The infectious titer (TCID $_{50}$. infective doses for $50 \%$ of cell cultures) used was $10^{5.61} \mathrm{TCID}_{50} / 50 \mu \mathrm{L}$ for BVDV and $10^{6.25} \mathrm{TCID}_{50} / 50 \mu \mathrm{L}$ for BoHV-1, determined by the Reed and Müench method [28].

\section{Herd-level case definition}

The herd-level case definition was based on the size of the population (cows aged $\geq 24$ months), number of females sampled, an intra-herd apparent prevalence of $50 \%$, and the sensitivity and specificity of the virusneutralization test of 95 and 99.5\% for BVDV [29] and 94.4\% and 93.2\% for BoHV-1 [30], respectively, with the goal of obtaining a herd sensitivity and specificity of $\geq 90 \%$. After simulations using Herdacc software, a herd was deemed positive for BVDV when at least one positive animal was detected, and for BoHV-1 infection, a herd was considered positive if it included at least one

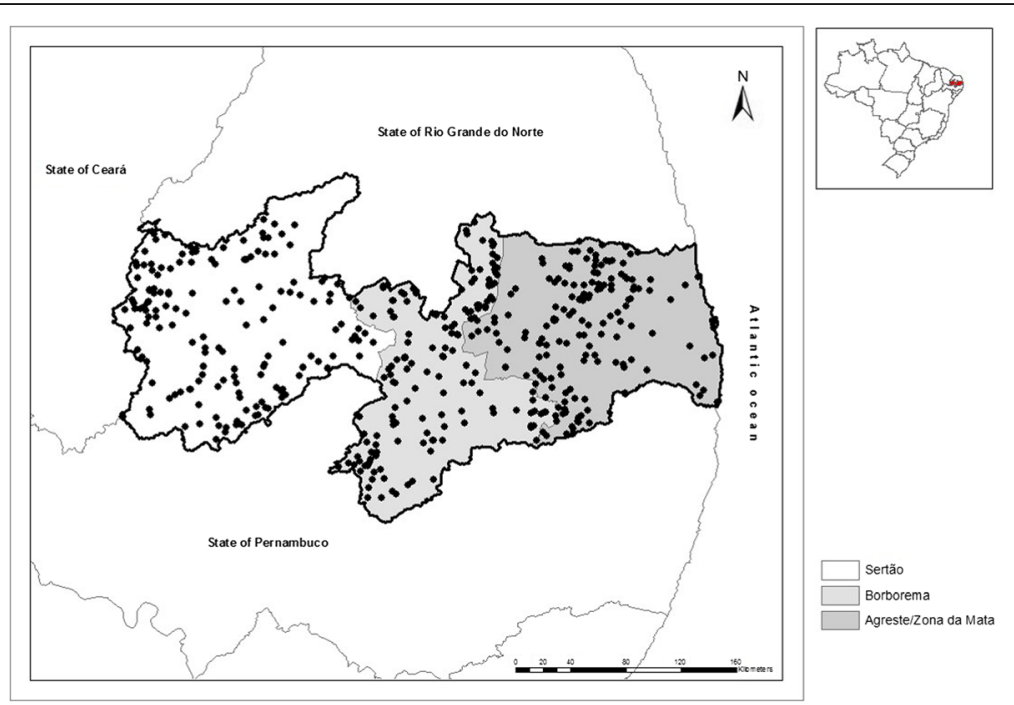

Fig. 1 Spatial localization of cattle herds in the State of Paraíba, Northeastern Brazil, according to sampling stratum. Detail shows Paraíba state within Brazil 
positive animal in herds of up to seven females; two positive animals in herds of 8-99 females; and three positive animals in herds with more than 99 females.

\section{Apparent prevalence calculations}

EpiInfo 6.04 software was used to calculate the apparent prevalences and respective confidence intervals [31]. Stratified random sampling was used to calculate the herd-level prevalence in the state of Paraíba [32]. The required parameters were as follows: (a) condition of the herd (positive or negative), (b) sampling stratum to which the herd belonged, and (c) statistical weight. The statistical weight was determined by applying the following formula [31]:

$$
\text { Weight }=\frac{\text { number of herds in the stratum }}{\text { number of herds sampled in the stratum }}
$$

The calculation of the herd-prevalence per sampling stratum employed the sampling design of a simple random sample by using the following parameters: (a) number of positive herds and (b) number of herds sampled in the stratum.

\section{Spatial analysis}

Identification of the herd, geographical coordinates and results of serological tests were included in a database for spatial analysis. Firstly, the Cuzick-Edwards' knearest neighbor method [33] was used to detect the possibility of spatial clustering at herd level using the ClusterSeer 2.5.1 software (BioMedware, Ann Arbor, MI, United States). Existence of potential spatial clustering was analyzed at each of the first 10 neighborhood levels, and the overall $p$-value was adjusted for multiple comparisons with the Simes approach. In a second step, scan statistics by the SatScan software version 9.0 [34] was used to identify local clusters of positive herds. A Bernoulli model was applied, the scanning window was circular, and the spatial size of scan window was limited to $25 \%$ of the total population. Because of the high herdlevel prevalences for BVDV and BoHV-1, analysis was not run on herd-level, and then considering within-herd prevalence. The statistical significance level was set as
0.05 and the maps were constructed with the ArcGIS software.

The kriging method was used to estimate the spatial pattern of apparent within-herd prevalence of BoHV-1 and BVDV. By this method, it is possible to produce a smooth surface of predicted prevalence and a map of prediction variance [35]. Kriging is based on the spatial correlation between measurements which is modelled by the semivariogram, and work well on stationary and non-stationary rates [36]. Directional semivariograms in four directions (north, north-east, east, south-east) were fitted to test for anisotropy. It was used an exponential model described below and fitted to the sample semivariogram [35]:

$$
\gamma(d)=C_{o}+C\left(1-\exp \left(-\frac{d}{a}\right)\right)
$$

where the parameters were nugget $\left(c_{o}\right)$, partial sill $(c)$, and range $(a)$.

\section{Results}

Figure 1 shows the spatial location of the herds in the state of Paraíba. The herd-level prevalence for BVDV and BoHV-1 infections in Paraíba were, respectively, 65.5\% (95\% CI: 61.1-69.7) and 87.8\% (95\% CI: 84.590.5) (Table 1). Two proprieties were excluded because they showed errors in their geographic coordinates, totaling 476 herds used in the spatial analysis. Figure 2 shows the spatial localization of positive and negative herds for BVDV (Fig. 2a) and BoHV-1 (Fig. 2b). The average apparent within-herd prevalence of BVDV was $31.8 \%$, ranging from $0 \%$ to $100 \%$, and for BoHV-1 it was $62.4 \%$ ranging from $0 \%$ to $100 \%$. Figures 3 and 4 show the kriging estimate of the apparent within-herd prevalences for BVDV and BoHV-1, respectively.

Sample semivariograms with fitted exponential model are shown in Fig. 5. For BVDV, parameters were: nugget $=0.02$, partial sill $=0.10$, and range $=13.9 \mathrm{~km}$; and for BoHV-1, parameters were: nugget $=0.01$, partial sill $=$ 0.10 , and range $=13.0 \mathrm{~km}$. The predicted prevalence was highest (0.42-0.75) for BVDV (Fig. 3a) in the west, north and eastern part of Sertão and in the central and eastern part of Agreste/Zona da Mata. For BoHV-1 (Fig. 4a), the

Table 1 Census data of the cattle population in the State of Paraíba, Northeastern Brazil, according to sampling stratum, and herd-

\begin{tabular}{|c|c|c|c|c|c|c|c|c|}
\hline \multirow{2}{*}{ Sampling stratum } & \multirow{2}{*}{$\begin{array}{l}\text { No. of } \\
\text { herds }\end{array}$} & \multirow[t]{2}{*}{ Tested } & \multicolumn{3}{|l|}{ BVDV } & \multicolumn{3}{|l|}{ BoHV-1 } \\
\hline & & & Positive & Prevalence & $95 \% \mathrm{Cl}$ & Positive & Prevalence & $95 \% \mathrm{Cl}$ \\
\hline Sertão & 24,356 & 159 & 118 & 74.2 & {$[66.8-80.4]$} & 145 & 91.2 & {$[85.6-94.7]$} \\
\hline Borborema & 11,603 & 160 & 79 & 49.4 & {$[41.7-57.1]$} & 130 & 81.3 & [74.4-86.6] \\
\hline Agreste/Zona da Mata & 18,398 & 159 & 102 & 64.2 & {$[56.4-71.3]$} & 139 & 87.4 & [81.3-91.8] \\
\hline Stateof Paraíba & 54,357 & 478 & 299 & 65.5 & {$[61.1-69.7]$} & 414 & 87.8 & [84.5-90.5] \\
\hline
\end{tabular}
level prevalence for BVDV and BoHV-1 

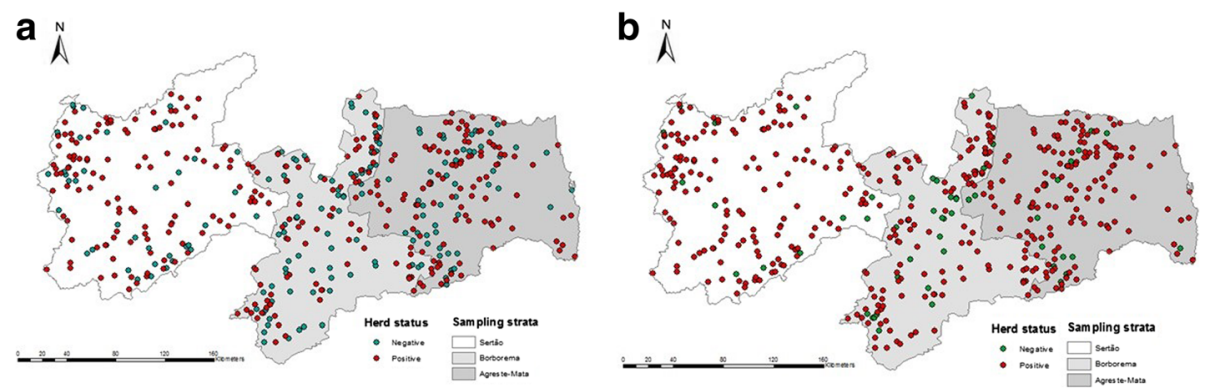

Fig. 2 Spatial localization of positive and negative herds in the State of Paraíba, Northeastern Brazil: a Herd status of BVDV; b Herd status of BoHV-1

highest predicted prevalence $(0.74-0.97)$ was in some local areas across Sertão and thoughout the eastern part of Agreste/Zona da Mata. The prediction variance reflects the location of tested herds: low values in the western part of Sertão and north, central and southern part of Agreste/ Zona da Mata for BVDV (Fig. 3b) and north and central part of Agreste/Zona da Mata for BoHV-1 (Fig. 4b), where herd density was high.

The Cuzick-Edwards' test identified statistically significant $(P<0.05)$ spatial clustering of BVDV and BoHV-1 cases at $k=18$ and $k=7$ neighborhood levels, respectively. Using Bernoulli model, six significant clusters were detected for BVDV and one significant cluster for BoHV-1 (Table 2, Fig. 6). There was no spatial overlap among clusters. For BVDV, a primary cluster covered the eastern Sertão region, with 11 herds, radius of $24.10 \mathrm{~km}$ and the risk for infection was 2.21 (relative risk $(R R)=2.21$; $P<0.001)$ times higher in herds located inside cluster than in those located elsewhere. The others significant BVDV clusters were smaller, involving one or two herds in Agreste/Zona da Mata region, near the border of the Borborema mesoregion, however, with a high relative risk. The BoHV-1 cluster covered the Agreste/Zona da Mata region with a radius of $77.17 \mathrm{~km}$ and a relative risk of $1.27(P<0.001)$, with 103 cases.

\section{Discussion}

In Brazil, prevalence rates of BVDV range from $22.2 \%$ to $85.4 \%[18,37,38]$, and seropositivity frequencies of BoHV-1 between $18 \%$ and $90 \%$ were frequently observed in non-vaccinated herds throughout the different geographical areas of Brazil [39-41]. In the Northeastern Brazil, seroprevalences for BVDV infection of $72.6 \%$ [42] and $51.1 \%$ in family farms [43] in Pernambuco state, and for BoHV-1 infection of 79.5\% [44] also in Pernambuco state, 62.67\% [45] in Sertão of Paraíba and 63.23\% [46] in Maranhão state have been reported. The herd-level seroprevalences for BVDV (65.5\%) and BoHV-1 (87.8\%) estimated for Paraíba state in this survey indicate that these viruses are present in most herds of the state.

In this work, six significant clusters were detected for BVDV infection and one significant cluster for BoHV-1. Similar results were found by kriging and SatScan for identification of risk areas (location of areas with high apparent within-herd prevalence) for BVDV and BoHV-1 infections: the western part of Sertão for BVDV and the western part of Agreste/ Zona da Mata for BoHV-1.

The primary cluster for BVDV was detected in the Sertão region, with a radius of $24.10 \mathrm{~km}$, and covering its eastern region. The Sertão was the stratum of higher prevalence for BVDV and is bordered on the north by Rio Grande do Norte state, west by Ceará
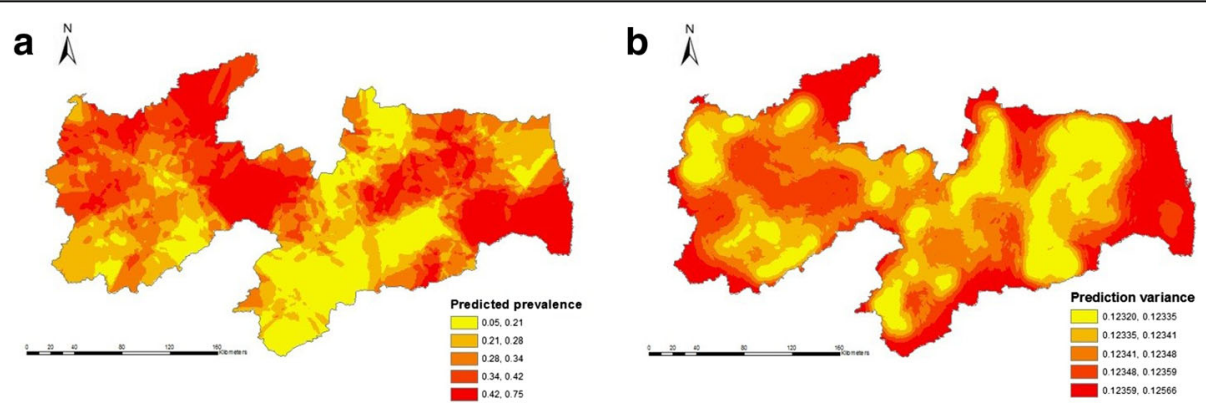

Fig. 3 Apparent within-herd prevalences for BVDV in the State of Paraíba, Northeastern Brazil: a) Kriging surface of predicted apparent prevalence and (b) the variance of kriging estimates of predicted apparent prevalence 

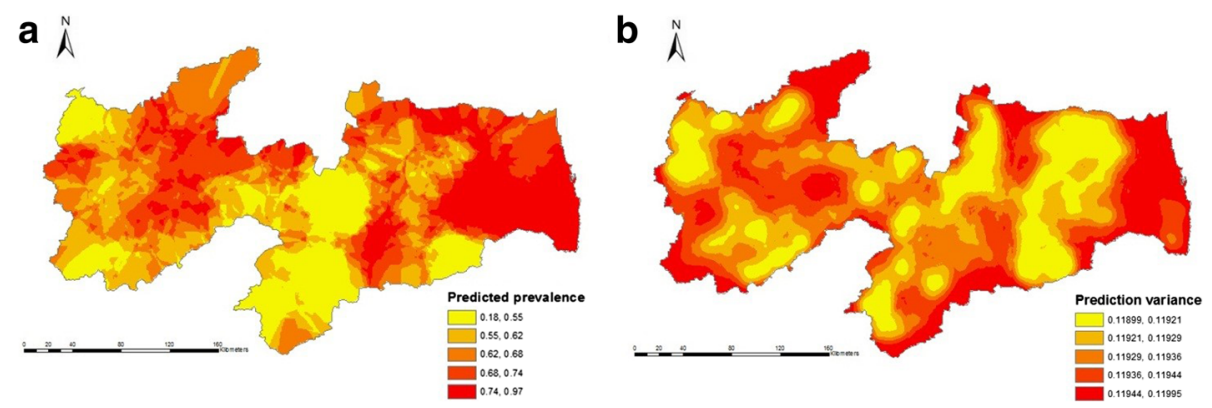

Fig. 4 Apparent within-herd prevalences for BoHV-1 in the State of Paraíba, Northeastern Brazil: a Kriging surface of predicted apparent prevalence and (b) the variance of kriging estimates of predicted apparent prevalence

state, and south by Pernambuco state. Border regions are always associated as risk factors, since in these regions there are large circulations of animals due to intense trade and often without knowledge of the health status of animals [47-49]. This circumstance corroborates what happens in the Sertão, where most of the properties are familiar or subsistence, predominating the mixed exploration, semi-confined farming, low technification and no veterinary assistance [50], increasing the risk in the herds of these properties.

Furthermore, recently BVDV was isolated in a herd in Pombal, a municipality of the Sertão mesoregion [51]. Knowing that PI animals are the main sources of infection of BVDV, and animal purching and pasture rental were identified as risk factors associated with herd-level seroprevalence for BVDV infection in the State of Paraíba [52], it is important to consider that the cluster for BVDV may have PI herds. Ersbøll et al. [53] in a study on the dynamics of BVDV infection among neighboring herds in Denmark found that the presence of PI-herds increased the risk of a herd becoming infected (PI-herd), showing odds ratios (OR) of 1.37, 1.40 and 1.70 for 1,2 , and $\geq 3$ PI-herds in the neighborhood, respectively, as well as the risk of becoming a PI-herd was negatively associated with the mean distance from the neighboring herds $(\mathrm{OR}=0.7$ for an increase of $1 \mathrm{~km})$, concluding that the occurrence of PI-herd in a certain area has influence on the risk of a neighbor herd becoming infected.

In Brazil, Hein et al. [54] found two BVDV clusters of dairy herds in the Arroio do Meio region, Rio Grande do Sul state, a primary $(P=0.391)$ and a secondary $(P=$ 0.773 ) by scanning analysis, but both without statistical significance. According to the author, the occurrence of no association may have been due to the scan test limitation or because transmission of the virus via aerosols or other vehicles is not an effective way to disseminate. Kirchgessner et al. [55] in an exploratory cluster analysis identified clusters in different locations for domestic livestock and white-tailed deer in New York state, United States, suggesting that BVDV is maintained independently in domestic livestock herds in the western part of the state and in the white-tailed deer population in the northwestern part. According to the authors, the spatial point pattern analyses provide information
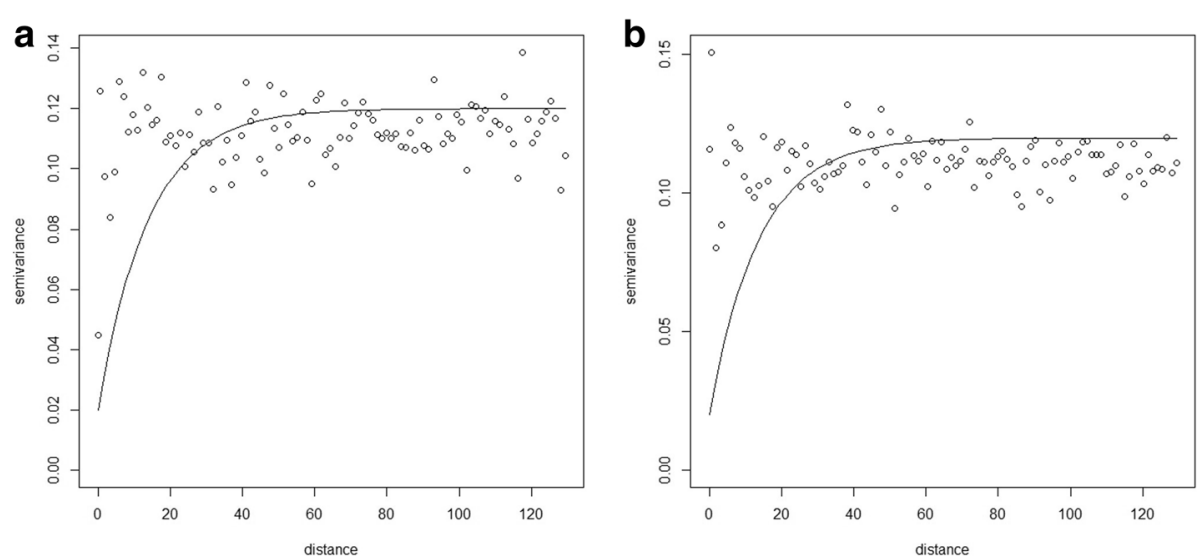

Fig. 5 Sample semivariograms with fitted model (solid line) used to generate kriging surface of predicted within-herd prevalence of BVDV (a) and $\mathrm{BoHV}-1$ (b) 
Table 2 Statistically significant clusters of herds with a high within-herd prevalence of BVDV and BoHV-1 in the state of Paraíba, Northeastern Brazil

\begin{tabular}{|c|c|c|c|c|c|}
\hline \multirow{2}{*}{$\begin{array}{l}\text { Radius } \\
(\mathrm{km})\end{array}$} & \multirow{2}{*}{$\begin{array}{l}\text { No. of } \\
\text { herds } \\
\text { in } \\
\text { cluster }\end{array}$} & \multicolumn{2}{|c|}{ No. of cases in cluster } & \multirow[t]{2}{*}{$\mathrm{RR}^{\mathrm{a}}$} & \multirow[t]{2}{*}{$p$-value } \\
\hline & & Observed & Expected & & \\
\hline \multicolumn{6}{|l|}{$B V D V$} \\
\hline $24.10^{b}$ & 11 & 55 & 25.87 & 2.21 & $<0.001$ \\
\hline 2.11 & 2 & 8 & 2.59 & 3.11 & 0.045 \\
\hline 0 & 1 & 13 & 4.53 & 2.90 & 0.004 \\
\hline 0 & 1 & 10 & 3.23 & 3.12 & 0.005 \\
\hline 0 & 1 & 10 & 3.23 & 3.12 & 0.005 \\
\hline 0 & 1 & 10 & 3.23 & 3.12 & 0.005 \\
\hline \multicolumn{6}{|l|}{ BoHV-1 } \\
\hline 77.17 & 103 & 359 & 297.39 & 1.27 & $<0.001$ \\
\hline
\end{tabular}

${ }^{\text {a }}$ Relative risk

bPrimary cluster

necessary for the epidemiological risk assessment that should precede the development of any regional BVDV management plan.

The significant BoHV-1 cluster $(P<0.001)$ showed a radius of $77.17 \mathrm{~km}$ with 103 herds whose 359 animals were positive when it was expected 297 positive animals, and involved a large part of the Agreste/Zona da Mata stratum, which has a high herd-level prevalence (87.4\%). Despite the seroprevalence is high throughout the state, the presence of a significant BoHV-1 cluster requires epidemiological interpretation of its spatial distribution and, consequently, the decisions based on that evidence
[56]. The mesoregions of Agreste and Zona da Mata had the highest rainfall in the state and a bovine livestock characterized by dairy farms and predominant confined rearing [50]. Miranda et al. [57] detected BoHV-1 clusters in southeastern Brazil and observed that disease clusters may occur either because herds share common risk factors or via transmission between herds through the movement of infected animals. The high prevalence of BoHV-1 in the Agreste/Zona da Mata stratum and the presence of cluster suggest that the relationship between the cases and the spread of the virus is due to the proximity of the animals in the herd [20]. BoHV-1 clusters were detected in the state of Rio Grande do Sul, in which the most significant $(P=0.00027)$ had a radius of $122.33 \mathrm{~km}$, with 173 properties, 109 positive animals, and $R R$ of 1.31, showing a moderate presence of BoHV1 infection in the southern herds [20].

In addition to the presence of PI animals for BVDV infection and purchasing untested cattle, other environmental or management factors may be influencing the intra and inter herd transmission for both infections in the state of Paraíba, mainly in high-risk areas. Such factors could be the lack of biosafety procedures in herds, extensive breeding, mixing cattle of different ages and from multiple sources, communal grazing and absence of vaccination.

In the risk mapping described in this study, there is a significant relation between the spatial effect and the development of the diseases, indicating that there are some important predisposing factors in the occurrence of infections studied. The herds of Paraíba and neighbor's

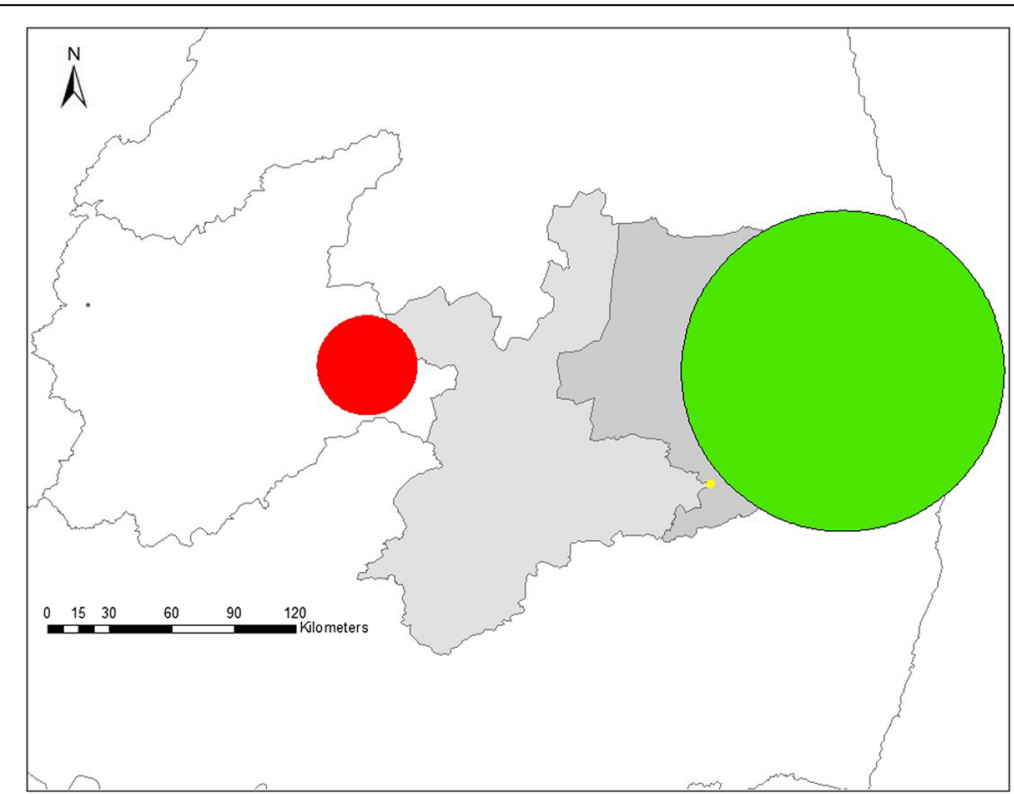

Fig. 6 Significant clusters of herds with a high apparent within-herd prevalence of BVDV (primary cluster: red, secondary clusters: yellow) and BoHV-1 (green) 
states might be sharing common risk factors or transmission routes among herds through the movement of infected animals, animal purchasing without the knowledge of the health status of animals, pasture rental, or absence of permanent veterinary assistance.

There may be other variables not considered in this work that can determine the spatial distribution pattern for both BVDV and BoHV-1 infections in a particular area. These variables may be potential risk factors that influence a higher risk of disease in areas of greater spatial effect, therefore, further works should be considered.

\section{Conclusions}

The spatial analysis enabled the identification of spatial clustering of risk for BVDV and BoHV-1 in the state of Paraíba. The clusters detected contemplated different areas of the state, with BVDV cluster located in the Sertão stratum and BoHV-1 in Agreste/Zona da Mata stratum. Through the risk mapping, it was possible to identify the areas in which the risk is significantly elevated, coinciding with areas where there are borders with other states and in which there is a high movement of animals. Clusters detection analysis enabled a better view of the occurrence of the BoHV-1 and BVDV and its result indicates the highest risk areas in the state of Paraíba, facilitating control strategies for specific actions and directed to those areas.

\section{Abbreviations}

BoHV-1: Bovine Herpesvirus type 1; BVDV: Bovine Viral Diarrhea Virus; GPS: global positioning system; OR: odds ratio; PI: persistently infected; RR: Risk Relative; SEDAP: Agricultural and Livestock Defense Service of the State of Paraíba; $\mathrm{TCID}_{50}$ : 50\% Tissue culture Infective Dose

\section{Acknowledgements}

The authors would like to thank the SEDAP for help during the sample collection.

\section{Funding}

This study was funded by the Conselho Nacional de Desenvolvimento Científico e Tecnológico (CNPq), under the codes 471571/2011-3, 302131/ 2012-4, and 476596/2013-0.

\section{Availability of data and materials}

The dataset used and/or analyzed during the current study are available from the corresponding author on reasonable request.

\section{Authors' contributions}

LF conducted the serological diagnosis tests and drafted the manuscript. EP, AR and ES conducted the serological diagnosis tests. IC, AM, CS and CA conducted the field activities and study design, and were involved in the preparation of the methods. SA conceived the study, participated in its design and coordination of the study and performed the spatial analysis. All authors read and approved the final manuscript.

\section{Ethics approval}

The study was approved by the Ethics Committee of the Federal University of Campina Grande, Brazil — protocol number 48-2012.

\section{Consent for publication}

Not applicable.

\section{Competing interests}

The authors declare that they have no competing interests.

\section{Publisher's Note}

Springer Nature remains neutral with regard to jurisdictional claims in published maps and institutional affiliations.

\section{Author details}

${ }^{1}$ Laboratory of Transmissible Diseases, Academic Unit of Veterinary Medicine, Center of Rural Technology and Health, Federal University of Campina Grande, Patos, PB 58700-970, Brazil. 'Laboratory of Bovidae Viruses, Biological Institute, São Paulo, SP 04014-900, Brazil. ³ Department of Veterinary Medicine, Federal University of Paraíba, Areia, PB 58397-000, Brazil.

Received: 24 July 2017 Accepted: 6 March 2018

Published online: 20 March 2018

\section{References}

1. Del Fava C, Pituco EM, D'Angelo JL. Herpesvírus bovino tipo 1 (HVB-1): revisão e situação atual no Brasil. Rev Educ Cont Vet Med Zootec2002;5:300-312.

2. Del Fava C, Arcaro JRP, Pozzi CR, Júnior IA, Fagundes H. Manejo sanitário para o controle de doenças da reprodução em um sistema leiteiro de produção semi-intensivo. Arq Inst Biol. 2003;70:25-33.

3. Junqueira JRC, Freitas JC, Alfieri AF, Alfieri AA. Reproductive performance evaluation of a beef cattle herd naturally infected with the BoHV-1, BVDV and Leptospira hardjo. Semin: Cien Agrar. 2006;27:471-80.

4. Rodning SP, Givens MD, Marley MSD, Zhang Y, Riddell KP. Reproductive and economic impact following controlled introduction of cattle persistently infected with bovine viral diarrhea virus into a naive group of heifers. Theriogenology 2012; https://doi.org/10.1016/j.theriogenology.2012.05.031.

5. Newcomer BW, Givens D. Diagnosis and control of viral diseases of reproductive importance: Infectious Bovine Rhinotracheitis and Bovine Viral Diarrhea Vet Clin North Am - Food Anim Pract 2016; https://doi.org/10. 1016/j.cvfa.2016.01.011.

6. Lanyon SR, Hill Fl, Reichel MP, Brownlie J. Bovine viral diarrhoea: pathogenesis and diagnosis. Vet J. 2014; https://doi.org/10.1016/j.tvjl.2013. 07.024.

7. McClurkin AW, Littledike ET, Cutlip RC, Frank GH, Coria MF, Bolin SR. Production of cattle immunotolerant to bovine viral diarrhea virus. Can J Comp Med. 1984:48:156-61.

8. Rüfenacht J, Schaller P, Audigé L, Knutti B, Küpfer U, Peterhans E. The effect of infection with bovine viral diarrhea virus on the fertility of Swiss dairy cattle. Theriogenology. 2001;56:199-210.

9. Presi P, Heim D. BVD eradication in Switzerland - a new approach. Vet Microbiol 2010; https://doi.org/10.1016/j.vetmic.2009.09.054.

10. Hay KE, Ambrose RCK, Morton JM, Horwood PF, Gravel JL, Waldron S, et al. Effects of exposure to bovine viral diarrhoea virus 1 on risk of bovine respiratory disease in Australian feedlot cattle. Prev Vet Med. 2016; https://doi.org/10.1016/j.prevetmed.2016.01.025.

11. Nandi S, Kumar M, Manohar M, Chauhan RS. Bovine herpes virus infections in cattle. Anim Health Res Rev. 2009;10:85-98.

12. Biswas S, Bandyopadhyay S, Dimri U, Patra PH. Bovine herpesvirus-1 (BHV-1) - a re-emerging concern in livestock : a revisit to its biology, epidemiology, diagnosis, and prophylaxis.Vet Q 2013; https://doi.org/10.1080/016e52176. 2013.799301.

13. Raaperi K, Nurmoja I, Orro T, Viltrop A. Seroepidemiology of bovine herpesvirus 1 (BHV1) infection among Estonian dairy herds and risk factors for the spread within herds. Prev Vet Med. 2010; https://doi.org/10.1016/j. prevetmed.2010.06.001.

14. Raaperi $\mathrm{K}$, Orro T, Viltrop A. Epidemiology and control of bovine herpesvirus 1 infection in Europe. Vet J 2014; https://doi.org/10.1016/j.tvjl.2014.05.040.

15. Lucchese L, Benkirane A, Hakimi I, Idrissi A El. Seroprevalence study of the main causes of abortion in dairy cattle in Morocco. Vet Ital 2016; https://doi. org/10.12834/Netlt.388.1813.1

16. Affonso IB, Amoril JG, Alexandrino B, Buzinar, MG, Medeiros ASR, Samara SI, Anticorpos contra o Herpesvírus Bovino Tipo 1 (BoHV-1) nas dez regiões de planejamento do estado de Goiás, Brasil. Ci Anim Bras 2010; https://doi.org/ 10.5216/cab.v11i4.6318.

17. Fino TCM, De Melo CB, Ramos AF, Leite RC. Diarréia bovina a vírus (BVD) uma breve revisão. Rev Bras Med Vet. 2012;34:131-40. 
18. Flores EF, Weiblen R, Cargnelutti JF, Bauermann V, Spilki FR, Mori E, et al. Emerging animal viruses: real threats or simple bystanders? Pesq Vet Bras. 2013;33:1161-73

19. Thompson JA, Leite RMH, Gonçalves VSP, Leite RC, Bandeira DA, Herrmann $G P$, et al. Spatial and hierarchical variances and age covariances for seroprevalence to Leptospira interrogans serovar hardjo, BoHV-1 and BVDV for cattle in state of Paraíba, Brazil. Prev Vet Med. 2006; https://doi.org/10. 1016/j.prevetmed.2006.05.010.

20. Carpenter TE. Methods to investigate spatial and temporal clustering in veterinary epidemiology. Prev Vet Med. 2001; https://doi.org/10.1016/S01675877(00)00199-9.

21. Silva GS, Machado G, Santiago Neto W, Hein HE, Santos DV, Medeiros AAR et al. Estudo de prevalência e análise espacial de varredura do herpesvírus bovino no estado do Rio Grande do Sul (BoHV-1). In: $2^{\circ}$ Encontro Nacional de Epidemiologia Veterinária. Biológico. 2015;77(Suppl 1):11-64. http://www. biologico.sp.gov.br/uploads/docs/bio/suplementos/v77_supl_1/54.pdf. Accessed 07 Feb 2017

22. Cabrera AL, Willink A. Biogeografía de America Latina. Organización de los Estados Americanos: Washington; 1973.

23. Andrade-Lima D. The Caatinga dominium. Rev Bras Bot. 1981;4:149-53.

24. Batista JS, Riet-Correa F, Teixeira MMG, Madruga CR, Simões SDV, Maia TF. Trypanosomiasis by Trypanosomavivax in cattle in the Brazilian semiarid: description of an outbreak and lesions in the nervous system. Vet Parasitol. 2007;143:174-81.

25. IBGE. Instituto Brasileiro de Geografia e Estatística (IBGE). Censo agropecuário 2006. http://www.ibge.gov.br/estadosat/temas.php?sigla= pb\&tema=censoagro. (2006). Accessed 07 Feb 2017.

26. OIE, World Organization for Animal Health. Bovine Viral Diarrhea. In: Manual of Diagnostic Tests and Vaccines for Terrestrial Animals. http://www.oie.int/ fileadmin/Home/eng/Health_standards/tahm/2.04.07_BVD.pdf (2015) Accessed 07 Feb 2017

27. OIE, World Organization for Animal Health. Infectious Bovine Rhinotracheitis/ Infectious Pustular Vulvovaginitis. In: Manual of Diagnostic Tests and Vaccines for Terrestrial Animals, http://www.oie.int/fileadmin/ Home/eng/Health_standards/tahm/2.04.12_IBR_IPV.pdf (2010). Accessed 07 Feb 2017.

28. Reed $L$, Muench HA. Simple method of estimating fifty percent endpoints. Am J Hyg. 1938;27:493-7.

29. Corbett EM, Grooms DL, Bolin SR, Bartlett B, Grotelueschen DM, Corbett EM, et al. Use of sentinel serology in a bovine viral diarrhea virus eradication program. J Vet Diagn Investig 2011; https://doi.org/10.1177/1040638711403412.

30. Cárdenas AB, Arango CJJ, Maya JJM, Hirose JAM, Bernal AO. Comparison between three diagnostic tests to detect abortion caused by infectious bovine rhinotracheitis in dairy herds. Vet Méx. 2006;2:151-63.

31. Dean AG, Dean JA, Coulombier D, Brendel KA, Smith DC, Burton AH, et al. Epi info, version 6: a word processing, database, and statistics program for public health on IBM compatible microcomputers. Atlanta: Center for Diseases Control and Prevention; 1996. file:///C:/Users/Sergio\%20Santos/ Downloads/cdc_23189_DS1.pdf.

32. Thrusfield M. Veterinary epidemiology. 3rd ed. Oxford: Blackwell Science; 2007.

33. Cuzick J, Edwards R. Spatial clustering for inhomogeneous populations. J R Statist Soc B. 1990;52:73-104.

34. Kulldorff M, Nagarwalla N. Spatial disease clusters: detection and inference. Stat Med. 1995;14:799-810.

35. Bihrmann K, Nielsen SS, Toft N, Ersbøll AK. Spatial differences in occurrence of paratuberculosis in Danish dairy herds and in control programme participation. Prev Vet Med. 2012;103:112-9.

36. Gotway CA, Wolfinger RD. Spatial prediction of counts and rates. Stat Med. 2003:22:1415-32.

37. Quincozes CG, Fischer G, Hübner SDO, Vargas GDA, Vidor T, Brod CS. Prevalence and factors associated with bovine viral diarrhea virus infection in south of Rio Grande do Sul. Semina: Ciên Agrár. 2007;2:269-76.

38. Almeida LL, Miranda ICS, Hein HE, Neto WS, Costa EF, Marks FS, et al. Herdlevel risk factors for bovine viral diarrhea virus infection in dairy herds from southern Brazil. Res Vet Sci 2013; https://doi.org/10.1016/j.rvsc.2013.08.009.

39. Lovato LT, Weiblen $R$, Tobias FL, Moraes MP. Herpesvírus bovino tipo 1: inquérito soro-epidemiológico no rebanho leiteiro do Estado do Rio Grande do Sul. Brasil Ciênc Rural. 1995:25:425-30.

40. Takiuchi E, Alfieri AF, Alfieri AA. Bovine herpervirus type 1: infection and diagnosis methods. Semina: Ciên Agrár. 2001;1:203-9.
41. Dias JA, Alfieri AA, Gonc VSP. Seroprevalence and Risk factors of bovine herpesvirus 1 infection in cattle herds in the state of Parana. Transbound Emerg Dis 2013; https://doi.org/10.1111/j.1865-1682.2012.01316.x

42. Castro RS, Melo LEH, Abreu SRA, Muniz AMM, Albuquerque APS. Anticorpos neutralizantes contra pestivírus em soros bovinos do Estado de Pernambuco. Pesq Agropec Bras. 1993;28:1327-31.

43. Rêgo JMP, Batista Filho AFB, Oliveira PRF, Borges JM, França CAB, Ribeiro CP, et al. Epidemiological analysis of infection by the bovine viral diarrhea virus on family farms in Brazil. Semina: Ciên Agrár 2016; https://doi.org/10.5433/ 1679-0359.2016v37n6p4119.

44. Silva FS, Oliveira JMB, Batista Filho AFB, Ribeiro CP, Pituco EM, Pinheiro Junior JW. Seroepidemiological survey of infection bovine herpesvirus type 1 (BoHV-1) in cattle in the state of Pernambuco. Acta Sci Vet. 2015;55:1-11.

45. Melo CB, Azevedo EO, Alfaro AEP, Lobato ZIP, Lobato FCF, Leite RC. Anticorpos neutralizantes contra herpesvirus bovino 1 (HVB 1) em bovinos do sertão da Paraíba. Ciênc Vet Tróp. 1999;2:43-4.

46. Freitas EJP, Lopes CER, Moura Filho JM, Sá JS, Santos HP, Pereira HM. Frequency of antibodies against bovine herpesvirus type 1 (BoHV-1) in beef cattle not vaccinated. Semina: Ciên Agrár. 2014; https://doi.org/10.5433/ 1679-0359.2014v35n3p1301.

47. Alban L, Stryhn H, Kjeldsen AM, Ersboll AK, Skjoth F, Christensen J, et al. Estimating transfer of bovine virus-diarrhoea virus in Danish cattle by use of register data. Prev Vet Med. 2001;52:133-46.

48. Gates MC, Woolhouse MEJ, Gunn GJ, Humphry RW. Relative associations of cattle movements, local spread, and biosecurity with bovine viral diarrhoea virus (BVDV) seropositivity in beef and dairy herds. Prev Vet Med. 2013; https://doi.org/10.1016/j.prevetmed.2013.07.017.

49. Gates MC, Humphry RW, Gunn GJ, Woolhouse MEJ. Not all cows are epidemiologically equal : quantifying the risks of bovine viral diarrhoea virus (BVDV) transmission through cattle movements. Vet Res 2014; https://doi. org/10.1186/s13567-014-0110-y.

50. Clementino IJ, Pimenta CLRM, Fernandes LG, Bezerra CDS, Alves CJ, Dias RA et al. Characterization of cattle raising in Paraíba state, northeastern Brazil. Semina: Ciên Agrár. 2015; https://doi.org/10.5433/1679-0359.2015v36n1 p557.

51. Weber MN, Silveira S, Machado G, Groff FHS, Mósena ACS, Budaszewski RF, et al. High frequency of bovine viral diarrhea virus type 2 in southern Brazil. Virus Res 2014; https://doi.org/10.1016/j.virusres.2014.07.035

52. Fernandes LG, De Campos Nogueira AH, De Stefano E, Pituco EM, Ribeiro $C P$, et al. Herd-level prevalence and risk factors for bovine viral diarrhea virus infection in cattle in the state of Paraíba, northeastern Brazil. Trop Anim Health Prod 2015; https://doi.org/10.1007/s11250-015-0937-x.

53. Ersbøll AK, Ersbøll BK, Houe H, Alban L, Kjeldsen AM. Spatial modelling of the between-herd infection dynamics of bovine virus diarrhoea virus (BVDV) in dairy herds in Denmark. Preev Vet Med 2010; https://doi.org/10.1016/j. eprevetmed.2010.08.004.

54. Hein HE, Payão C, Costa EDF, Almeida LL, Gustavo L. Análise espacial de Diarréia Viral Bovina (BVD) em propriedades leiteiras na região de Arroio do Meio (RS). 2008. http://www.lume.ufrgs.br/handle/10183/45529. Accessed 07 Feb 2017.

55. Kirchgessner MS, Dubovi EJ, Whipps CM. Spatial point pattern analyses of bovine viral diarrhea virus infection in domestic livestock herds and concomitant seroprevalence in wild white-tailed deer (Odocoileus virginianus) in New York state, USA. J Vet Diagn Investig 2013; https://doi. org/10.1177/1040638713479121.

56. Ávila LN, Perez AM, Neto JSF, Ferreira F, Telles EO, Dias RA, et al. Análise de detecção de cluster na caracterização espaço- temporal da tuberculose bovina no Estado da Bahia. Pesq Vet Bras. 2013;33:1313-8.

57. Miranda ICS, Hein HE, Costa EF, Machado G, Neto WS, Marks FS, et al. Prevalence survey and spatial analysis of bovine herpesvirus. In: International Symposia on veterinary epidemiology and economics (ISVEE). 2012. http://www.sciquest.org.nz/node/81153. Accessed 07 Feb 2017. 